\title{
$4+$ \\ Den nya kvinnan som pojke \\ Kvinnlig maskulinitet i Ellen Idströms Tvillingsystrarna
}

I både svensk flickbok och svensk kvinnorörelse utgjorde I890-talet en dynamisk period. Reformer som rörde kvinnans utbildning, arbete och myndighet hade förbättrat i synnerhet den ogifta kvinnans ställning och en ny generation kvinnor sökte sig till universitet och ut $\mathrm{i}$ arbetslivet. Dessa "nya kvinnor" kännetecknades av en större rörlighet och synlighet i samhället, och kom att bli en av modernitetens representanter $i$ det sena I800-talets kultur. ${ }^{376}$ Parallellt publicerades fler flickböcker än tidigare och nya författare trädde in på scenen. Under decenniet gavs några av de mest uttalat politiska flickböckerna under undersökningsperioden ut. Kristin Hallberg har utnämnt dem till"de första - de djärvaste" och framhåller i synnerhet Meyersons Flickor emellan från $\mathrm{I} 890$ och Idströms Tvillingsystrarna från I $893 .{ }^{377} \mathrm{I}$ dessa texter träder en mer självmedveten flicktyp fram, med stora framtidsvisioner och en önskan om att stå på egna ben. Vuxenlitteraturens nya kvinna fick i dessa flickböcker en lika modern och debattlysten lillasyster.

Den snabba förändringen skapade en känsla av optimism och befrielse, men också en rädsla för att traditionella värden skulle gå förlorade. Runt sekelskiftet I 900 blev motståndet mot kvinnans emancipation mer aggressivt och till och med tidigare förespråkare för kvinnosaken kunde hävda att frigörelsen gått för långt. Även inom flickboksgenren uttrycktes tvekan inför utvecklingen. I exempelvis förordet till "Mera sådant" eller En nollas historia från 1906 ställde sig Ottilia Westermark undrande till om den första generationen kvinnosakskvinnor skulle ha givit sitt godkännande till samtidens nya kvinnor:"Att kvinnan då icke tänkte sig 
en så utvecklad och skarp emancipation, som våra dagar kunnat framvisa, är jag viss om - och jag undrar, om föregångskvinnan ens önskat att se den så utvecklad, som den nu i all sin karlavulenhet blifvit." ${ }^{378}$ Inom kvinnorörelsen skedde en förskjutning från liberala idéer om individers lika rättigheter till ett särartstänkande som den dominerande ideologin. ${ }^{379}$ Kvinnorna skulle försöka att influera samhället och kulturen utifrån sina unika kvinnliga egenskaper snarare än eftersträva männens positioner.

Ellen Keys publicerade föreläsning Missbrukad kvinnokraft (I 896) har betraktats som en vändpunkt. ${ }^{380}$ Tidigare hade motståndare till kvinnors frigörelse vanligen hävdat att den stred mot traditionen eller en gudomlig ordning. ${ }^{381}$ Key formulerade sin kritik mot kvinnorörelsen utifrån en socialdarwinistisk ståndpunkt. Därmed blev kvinnoemancipationen ett hot mot folkets hälsa och överlevnad. I föreläsningen diskuterades biologiska skillnaders sociala implikationer och Key framhöll kvinnans känsloliv och moderlighet som hennes främsta egenskaper. Hon hävdade att kvinnorörelsens företrädare ville uppfostra kvinnor till att bli som män och utföra deras arbete. Även om Key förespråkade jämställdhet mellan könen, menade hon att den riktning som emancipationen tagit riskerade att försvaga den kvinnliga egenarten, vilket kunde få katastrofala följder för kvinnan, äktenskapet och samhället som helhet. ${ }^{382}$

Missbrukad kvinnokraft mötte stark kritik från flera framträdande personer inom kvinnorörelsen och föreläsningen betraktades som ett reaktionärt utspel från en tidigare förespråkare för kvinnans rättigheter. ${ }^{383}$ En av de skarpaste kritikerna var Ellen Idström. Runt sekelskiftet I900 var hon verksam som författare och en av grundarna till Föreningen för kvinnans politiska rösträtt i Göteborg, men i dag är hon främst ihågkommen för sin replik till Key ${ }^{384}$ I Misslyckad kvinnokraft (I 896) påstod Idström att Key bortsåg från kvinnans historiska och sociala sammanhang i sin beskrivning av könsegenskaper och att hon bejakade kvinnlighetens djuriska sida, när hon upphöjde moderlighet till kvinnans främsta kännetecken. Till skillnad från Key menade Idström att framtidens kvinnor inte borde begränsas av biologiska skillnader eller den roll de haft tidigare i historien. ${ }^{385}$ 
Enligt Idström framstod en påtvingad kvinnlighet som ett större hot mot kvinnan än den maskulinisering Key och andra fruktade. I debutromanen Tvillingsystrarna beskrivs skapandet av en ny kvinna genom ett experiment där en flicka uppfostras som pojke. Hennes utveckling kontrasteras mot tvillingsysterns, som uppfostras som flicka. Texten utforskar hur syskonens olika uppväxter påverkar deras fysik, moral och mentala kapacitet. I följande kapitel kommer jag att analysera vad maskuliniseringsprocessen innebär i Tvillingsystrarna och hur den kan relateras till samtidens debatt om könen och ett föreställt kvinnligt medborgarskap. Idströms flickbok beskriver såväl kvinnans utvecklingspotential som de hinder hennes utveckling kunde möta i det samtida samhället. I en tid då essentialistiska idéer om den sanna kvinnans natur vann ny mark i Sverige riktade Tvillingsystrarna fokus mot hur normativa föreställningar om kön skapades och upprätthölls. Snarare än att försöka fastställa vad kvinnan är utforskar denna roman vad hon skulle kunna bli.

\section{Kvinnlig maskulinitet}

Tvillingsystrarna ingår i en tradition med flickor som klär sig eller uppför sig som pojkar inom ungdomslitteraturen. Pojkflickan dök upp i nordamerikanska flickböcker under första hälften av I800-talet och blev efter Jo i Alcotts Little Women en vanlig karaktär. ${ }^{386}$ Även om många litterära pojkflickor har gemensamma egenskaper, som ett viss mått av vildhet och en förkärlek för utomhuslekar, formuleras de utifrån sin tids könsdiskurser och förändras i relation till den politiska, sociala och ekonomiska utvecklingen. ${ }^{387}$ Uppfostringsexperimentet i Tvillingsystrarna utgör ett inlägg i samtida debatter om flickors utbildning och hälsa, den kvinnliga reformdräkten, rösträtt och valbarhet, samt kvinnors arbetsområden. Vad berättelsen framför allt inriktas på är rädslan för att samhällsförändringarna skulle göra flickor och kvinnor mer manliga, och att kvinnligheten riskerade att förändras eller gå förlorad. Idströms roman både leker med och avvisar en dylik oro. Genom skildringen av tvillingsystrarnas uppväxt omvärderas samtida normer om kvinnliga och manliga egenskaper. Denna omvärdering resulterar i skapandet av en ny, mer manlig kvinna. 
Tvillingmotivet i Tvillingsystrarna används för att etablera en gemensam utgångspunkt, varifrån flickorna under påverkan av uppfostran och andra sociala omständigheter utvecklas åt skilda håll. ${ }^{388} \mathrm{Vid}$ sex års ålder adopteras systrarna Anna och Gunlög av varsin kvinnlig släkting efter moderns död. I texten poängteras hur lika till utseendet barnen är. Anna sägs vara "så lik henne [Gunlög] en tvillingsyster gärna kan vara det". ${ }^{389}$ De har emellertid skilda personligheter och den tystlåtna Gunlög bedöms vara den mer lovande av de två. När"den gamla draken" ${ }^{390}$ faster Ebba tilldelas den andra flickan svär hon att hämnas på släktingarna:

Jag skall uppfostra barnet till en skräck för dem. Deras kvinnor ha strängt hållit sig till den gamla ordningen och förblifvit kvinnor enligt det gamla receptet: märkdukar, matlagning, stickstrumpa, snörlif, behagsjuka, undergifvenhet under mannen och respekt för det"passande". Men nu skall jag sticka in en ulf i deras fårahjord. Flickan skall bli en sannskyldig flickpojke och uppfostras precis som en gosse - jaha, det skall hon. ${ }^{391}$

Annas hår klipps av och hon kläs i pojkkläder, medan Gunlög får lära sig att bli en sann kvinna av sin adoptivmor:"Jag skall göra henne till en äkta kvinna', säger moster Karna.'Sak samma om hon inte får så mycket vetande i sitt lilla hufvud - de där förlästa, säkra skolflickorna äro min fasa. Mild, huslig, intagande - en liten solstråle skall min flicka bli," 392 Liksom i flickböckerna om hushållsskolor ställs hushållssysslor mot intellektuellt arbete. Genom Karnas och Ebbas uppfostringsmetoder blottläggs hur dessa verksamheter associeras med olika föreställningar om manligt och kvinnligt. Båda kvinnorna sammankopplar inledningsvis kvinnlighet med passivitet, undergivenhet och hemmets värld, vilket är i linje med samtidens konservativa värderingar. I Idströms roman utmanas en gammaldags kvinna av en rebellisk ny flicka. Beskrivningen av tvillingarna som en varg och en solstråle förebådar även hur de kommer att påverka människorna i sin omgivning. Gunlög, som bekräftar samtidens normer, sprider ljus och glädje omkring sig. Den könsöverskridande Anna orsakar däremot splittring och förvirring, likt en ulv i en fårahjord.

Som ordet klargör definieras pojkflickan av en kombination av kvinn- 
liga och manliga egenskaper. Mitchell poängterar att flickor som under andra hälften av I 800-talet drömde om att vara pojke eftersträvade olika saker: "girls wanted active games, a serious education, and adult rights and responsibilities" ${ }^{393}$ På samma sätt har litterära pojkflickor skilda mål. Vissa karaktärer visar huvudsakligen en frustration över begränsande föreställningar om kvinnlighet, andra som Alcotts Jo längtar efter att vara en pojke och härmar män. ${ }^{394}$ I Female Masculinity (I998) beskriver Judith/Jack Halberstam hur maskulina kvinnor gjort kön och sexualitet på en mängd olika sätt från I 800-talet till nutid. Snarare än att betrakta kvinnlig maskulinitet som en imitation av manlighet, förespråkar Halberstam en vidare syn på kön som överskrider ett binärt tänkande. ${ }^{395}$ Fokus riktas mot en lesbisk kvinnlig maskulinitet och pojkflickor som identifierar sig med män, men också den maskulinisering som projicerats på exempelvis bastanta bondkvinnor eller kvinnliga atleter. ${ }^{396}$

Sekelskiftets svenska flickböcker tydliggör bredden i vad som har kodats som manliga beteenden bland kvinnor. Några exempel är en studentska i Meyersons Flickor emellan, en driftig affärsflicka som kallas Pojken i Elisabeth Kuylenstierna-Wensters När katten är borta, en manhaftig lesbian i Nybloms"Sju flickor" och den okynniga Signe, också kallad Pojken, i Wides Kamraterna på Forsbo som hade

en lång, rak figur utan höfter och fason i öfrigt, med håret kortklippt och rakt uppstruket samt ögon, som tycktes gå på jakt efter rof, d.v.s. något att skratta åt och göra spektakel af.

Först hade de alla trott, att det var en förklädd pojke, men det var då inte sant, fastän figur och fasoner och röst... ${ }^{397}$

Pojkens kropp, frisyr och sätt signalerar en så övertygande maskulinitet att flickkläderna framstår som en förklädnad.

Till skillnad från i Nybloms och Wides texter skildrar Tvillingsystrarna inte en ung kvinna som identifierar sig med män eller uttrycker ett samkönat begär utan berättelsen fokuserar på maskulina kvinnor $\mathrm{i}$ ett heterosexuellt sammanhang. Anna uppskattar den frihet som pojkskapet innebär, men uttrycker ingen önskan om att vara man och relationen till bästa vännen Maria beskrivs som "djup, men fri från allt'slisk', såsom 
hon brukade benämna flickors överdrifna förtjusning för hvarandra" ${ }^{398}$ Idströms roman undersöker en annan typ av maskulinisering som rör kvinnors utseende, utbildning och plats i samhället. Genom att Anna inte sammankopplas med en homosexuell kvinnlig maskulinitet går texten indirekt i polemik med några av samtidens fördomar om frigjorda kvinnor och deras påstådda önskan om att på alla sätt vara som män. ${ }^{399}$ Det innebär dock även att flickans utveckling stannar inom ett heteronormativt ramverk.

Tvillingsystrarna exponerar könade uppfostrings- och utbildningsmönster genom tvillingarnas olika barndomar. Annas uppfostran till pojke rör både hennes fysiska och intellektuella utveckling. Faster Ebba ger henne en utbildning som vanligen endast ges till"sönerna ur rika familjer" ${ }^{400}$ En manlig privatlärare anställs för att ge henne den kunskap det inte är möjligt för henne att få i närliggande flickskolor, vilket parallellt synliggör flickors begränsade utbildningsmöjligheter. Trots att kvinnor från 1870 tilläts att ta studentexamen som privatister fick de inte studera vid de statligt finansierade läroverken. Mot slutet av seklet fanns bara ett fåtal privata flickskolor som erbjöd möjligheten att ta studenten. För att stärka Annas kropp och främja hennes självständighet iordningställs en gymnastiksal åt henne och hon ges en häst, en båt, en bössa och ett trädgårdsland. Ett vilt och okynnigt beteende uppmuntras så länge Anna inte ljuger, är feg eller direkt elak. Denna typ av upproriskhet och ansvarslöshet utgjorde standarddrag i samtida diskurser om pojkskap. ${ }^{401}$ Som ofta är fallet i berättelser om pojkflickor sammankopplas maskulinitet i Idströms berättelse med frihet och oberoende:"Masculinity provided physical and geographical freedom: nonobstructive clothing, an athletic body, safe passage through public spaces that men made dangerous for those who wore skirts." 402 Uppfostran gör Anna självständig och orädd och hon ryggar inte ens för att röra sig ensam genom staden när det blivit mörkt.

Idströms roman ger flickan större frihet än vad som vanligtvis ansågs passande i det sena I 800-talet. En likartad fysisk och intellektuell utveckling återfinns i Mellins Öjungfrun från I 832, men där är den endast möjlig när flickan förflyttas bortom civilisationen. Mot slutet av seklet hade flickor större möjligheter till ett aktivt liv. Både läkare och 
den framväxande frilufts- och idrottsrörelsen menade att det var hälsosamt för barn att röra på sig. Alla sporter och gymnastiska övningar betraktades dock inte som passande för båda könen. Vissa aktiviteter ansågs vara för ansträngande eller tävlingsinriktade för unga kvinnor. Andra var olämpliga då flickorna riskerade att skada sig eller utveckla en manlig fysik. ${ }^{403}$ I Tvillingsystrarna är det en traditionellt kvinnlig uppfostran som framställs som det största hotet mot flickors hälsa och moral. Gunlög är i stort sett aldrig utomhus. Att gå på baler och teatern är viktigare för henne än att sköta sina studier. Mostern skämmer bort Gunlög och klär henne som en docka, vilket får henne att tro att hon är "en liten prinsessa". ${ }^{404}$ Hon och de andra flickorna får lära sig att det är kvinnligt att vara andra till lags: "en ung flicka måste tänka på att behaga" ${ }^{405}$ Resultatet blir att de framstår som tillgjorda och oärliga. Idströms roman beskriver hur pojkars uppfostran stärker dem till kropp och själ, samtidigt som den främjar självständighet och individualism. Flickor får lära sig att behaga, att vara vackra och beroende av andra, på bekostnad av intellekt och hälsa.

Berättelsens inledning etablerar en dikotomi mellan manligt och kvinnligt. Det finns inga andra alternativ än att uppfostras som flicka eller pojke för tvillingarna. Trots att Anna klär sig och uppför sig som en pojke, uppfattar omgivningen henne vanligtvis som en flicka och dömer henne därefter. Hennes otvungna rörelser och uppförande kritiseras för en avsaknad av kvinnlig grace av släktingarna. Anna sägs vara "en ryslig flicka med sina gossaktiga fasoner och sitt bullersamma, hurtiga sätt, som bjärt stack av mot deras egna flickors stillsamma, värdiga uppträdande - 'så som det passar en flicka" . ${ }^{406}$ Beteenden som i varje fall tolereras hos en pojke framstår som oacceptabla hos en flicka. Utifrån en manlig måttstock kommer emellertid Anna bättre till sin rätt. Hon tar studentexamen ett år i förtid och slår alla manliga deltagare i en skridskotävling. Tvillingsystrarna framhåller flickors intellektuella och fysiska kapacitet och motbevisar därigenom tankegångar om en biologisk determinism. Deras eventuella underlägsenhet på dessa områden beskrivs i stället som ett resultat av uppfostran och begränsande könsnormer. Flickans utveckling i romanen visar att hon kan göra allt en pojke kan så länge hon ges samma förutsättningar. 
Annas upplevelse av att vara annorlunda och utstött blir lika betydelsefull för hennes mognadsprocess som fasterns uppfostringsexperiment i sig. Idströms roman framhåller hur normer upprätthålls och konstrueras i interaktionen mellan människor. Anna har internaliserat omgivningens syn på henne som avvikande och önskar att hon vore mer som andra flickor:

Jag vet nog, att jag är faslig nu, men med tiden måste det bli bättre. Jag har förut tyckt, att det skall bli förskräckligt, när jag måste bli flicka igen och få kjolar. Men nu tänker jag annorlunda, och om du tillåter det, vill jag så gärna börja med detsamma. Jag kan ju redan i morgon få flickkläder och lära mig gå tyst och niga och allt det där. ${ }^{407}$

Det främsta skälet till att hon vill framstå som mer kvinnlig är att hon vill bli omtyckt och accepterad. Samtidigt leder omgivningens kritik till att hon utvecklas till en självständigt tänkande individ med stark moralkänsla. Då Anna själv är annorlunda bemöter hon samhällets utstötta med respekt. Hon blir exempelvis vän med de fattiga grannarna som systern undviker. Tvärtemot släktingarnas "ringaktande omdömen om henne, som de frånkände alla en flickas vekare, ömma instinkter, för att beskylla henne för onatur och brist på sann kvinnlig moral och känsla", uppvisar den maskulina Anna medkänsla, omtanke och lojalitet. Flickan som kläs och fostras som pojke visar sig bli mer"kvinnlig” än systern som får en flickuppfostran.

Även om båda könen framställs som kulturellt konstruerade i Idströms flickbok, associeras manlighet med ärlighet, styrka och natur medan kvinnlighet karakteriseras av bräcklighet och tillgjordhet. Det innebär att den maskulina flickan framställs som mer naturlig än den feminina systern. Idströms roman skriver fram en variation av manliga och kvinnliga framträdelseformer, men bejakar inte alla slags könsöverskridanden. Den negativa värderingen av kvinnlighet påverkar också feminina män. Annas och Gunlögs kusin Viktor beskrivs som"en sannskyldig mammas gosse” och precis som flickorna är han fäfäng, fysiskt svag och självisk. ${ }^{409}$ Inte heller alla typer av maskulinitet framställs i positivt ljus. När en annan av flickornas kusiner, Eva, börjar härma Anna, 
anammar den yngre flickan även männens dåliga vanor, som att röka och svära. Hon hävdar att kvinnor borde ha rätt att vara lika ohyfsade som män: ”Ja, men sau göra inte karrarne. De lägga nej gu' inte bann pau sig och dau mau ingen foudra af auss, att vi ska' görra det. För serr du, jag vill ha likställighet i det ena soum i det andrra." ${ }^{410}$ Den skånska dialekten används för att markera ett avståndstagande från uttalandet. Eva avfärdas som "obehaglig", vilket tydliggör att syftet med den nya flickans uppfostran inte är att förvandla henne till en man. ${ }^{411}$ Krav om jämställdhet skulle således inte missförstås som en önskan om att få hänge sig åt omoraliska handlingar. Anna understryker att hon endast vill ta efter män när det gäller"saker af allvar och vikt". ${ }^{412}$ Vissa påstått manliga och kvinnliga beteenden fördöms, oavsett om de återfinns hos män eller kvinnor. Enligt samma logik främjas högt värderade egenskaper som hälsa och ärlighet hos Anna genom att hon får en pojkes uppfostran, men i slutänden är det kvaliteter som värdesätts hos båda könen. På så vis undermineras successivt ett binärt könstänkande i texten.

Tvillingsystrarna leker med samtida stereotyper av emanciperade, manhaftiga kvinnor. Följderna av att göra flickor mer manliga vägs mot hur de påverkas av en traditionell uppväxt. Idströms svar till dem som oroade sig för att kvinnans förändrade levnadsvillkor skulle leda till att hennes kvinnlighet gick förlorad, var att en sådan kvinnlighet hur som helst inte var värd att rädda. I flickboken ifrågasätts kvinnlighet och manlighet som naturgivna företeelser genom att könen framställs som en effekt av uppfostran och social disciplinering. Som Karin Quimby har påpekat har pojkflickan i litteraturen ofta använts på ett liknande sätt för att exponera könet som instabilt. Karaktärstypen synliggör också olika strategier inom och utanför texten som eftersträvar att kontrollera hennes "queer energies" ${ }^{413}$ I Tvillingsystrarna skapar Annas tvetydiga könsposition kontinuerligt spänningar och hon benämns som flicka, pojke eller ett mellanting. En bekant i samma ålder beskriver Anna som "så snäll och treflig, att jag skulle tyckt riktigt bra om henne, bara hon varit riktig flicka eller riktig pojke". ${ }^{14}$ Trots pojkflickans många goda egenskaper undviker alla henne under barndomen, eftersom hon är annorlunda och svårklassificerad. Enligt Marjorie Garber är" one of the most consistent and effective functions of the transvestite in culture $[. .$.$] to indicate$ 
the place of what I call 'category crisis', disrupting and calling attention to cultural, social, or aesthetic dissonances". ${ }^{415}$ På liknande sätt fungerar flickan i pojkkläder i Tvillingsystrarna som en påminnelse om den flytande gränsen mellan könen. När släktingarna avvisar henne är det i ett försök att fördriva den instabilitet hon representerar i deras ögon.

\section{Kulturella kroppar}

Föreställningen om en naturlig och evig kvinnlig egenart utmanas kontinuerligt i Tvillingsystrarna. I texten undersöks ett vidare könsspektrum och hur olika kulturella förhållanden producerar en mångfald av kroppar i en skärningspunkt mellan bland annat kön, klass och etnicitet. Samtida kvinnoideal beskrivs som en relik från en svunnen tid. Det moderna, industrialiserade samhället har gjort kvinnans traditionella arbete överflödigt och förvandlat henne till "halft docka, halft ett besvärligt påhäng". ${ }^{16}$ Kvinnlighet och kvinnokroppar framställs som produkter av specifika historiska, sociala och nationella förhållanden. De är föränderliga till sin natur och varierar över tid. Framhävandet av kvinnlighetens historiska specificitet klargör att den nya tiden behöver en ny kvinna.

I Idströms flickbok skildras vuxenblivande som en process utan ett förutbestämt resultat. Det finns ingen sann kvinnlighet eller manlighet som karaktärerna naturligt växer in $i$. Till skillnad från många andra berättelser om pojkflickor väljer inte Anna själv att klä sig som pojke och klädseln speglar inte heller ett inre behov. Flickan beskrivs som ett trotsigt barn, men uppför sig inte på ett manligt sätt och uttrycker ingen önskan om att vara pojke. I stället är manligheten något som påtvingas henne. Kvinnlighetens attribut tas bokstavligen ifrån henne av faster Ebba, då hon klipper av flickans fläta och klär på henne pojkkläder:

$\mathrm{Nu}$ tár faster Ebba af henne klädningen och underkjolen - alltsammans ända in till det broderade linnet, och allt kastas föraktligt i en vrå. En gosskjorta trädes öfver hufvudet på henne, benen sticks i ett par klädesbyxor, en sjömansblus, krage och stöfletter fullborda toaletten, och Anna står där förvandlad till pojke. ${ }^{417}$ 
Utan de välbekanta flicktecknen blir Anna som en främling för sig själv. Hon försöker övervinna känslan av vilsenhet genom att upprepa "det är jag", som om hon tvivlade på att hon fortfarande är samma person. ${ }^{418}$ Den påtvingade manligheten exponerar könet som performativt eller, med Judith Butlers ord," a set of repeated acts within a highly rigid regulatory frame that congeal over time to produce the appearance of substance, of a natural sort of being" ${ }^{419}$ När Anna fått de nya kläderna uppmanas hon att uppföra sig som en pojke och instrueras att inte gråta eller vara vek. Genom att hon måste agera som pojke inkorporerar hon successivt vad som uppfattas som manliga drag i sin personlighet.

De olika levnadssätten påverkar flickornas hälsa och kroppar. Vid en jämförelse mellan tvillingarna poängteras de fysiska konsekvenserna av kvinno- och mansidealen:

\begin{abstract}
Vi voro lika stora och starka, när vi voro små, men nu är hon [Gunlög] ständigt klen och måste gnida sina kinder, om hon vill ha färg på dem, då däremot jag är frisk och stark som en bondjänta. Moster Karna låter henne gå på för många baler och äta för mycket slisk, och så har hon för lite rörelse i friska luften. Moster Karna är rädd, att det skulle göra henne ograciös och okvinnlig, om hon finge springa och rusta om ute $[\ldots]_{+}^{420}$
\end{abstract}

Kvinnliga praktiker framställs som hämmande för flickornas utveckling. De tillåts inte vara fysiskt aktiva, vilket resulterar i en bräcklig konstitution. Skillnaderna mellan flickornas kroppar framhävs när Annas välformade lemmar jämförs med Gunlögs "spindelben, [...] skrala och opålitliga”. ${ }^{221}$ Annas friska och starka kropp låter henne göra allt hon önskar medan systerns tunna ben knappt bär henne. Ytterligare en typ av kvinnokropp exemplifieras av Annas veka vän Maria som, till skillnad från den bortskämda Gunlög, uppvisar ett föredömligt kvinnligt kynne. Hon är självuppoffrande, vänlig och tålmodig, som en sann medelklassflicka. ${ }^{422}$ Denna idealbild kunde också beledsagas av en idealisering av skör fysik och sjuklighet. ${ }^{423}$ Idströms roman granskar detta ideal med kritisk blick. Marias död visar att inte ens den bästa bland flickor klarar att hantera fattigdomens umbäranden eller ett vanligt arbetsliv om hon fått en alltför skyddad uppväxt. Hennes veka kropp 
hindrar henne från att växa upp till en samhällsnyttig medborgare.

Liknelsen mellan Anna och en bondflicka i citatet ovan antyder att olika kroppar skapas intersektionellt i en samverkan mellan kön och andra kategorier som ålder, klass och etnicitet. I I 800-talets medicinska rådgivningslitteratur framställdes kvinnor från skilda sociala och etniska grupper med varierande fysiska kännetecken. Kvinnokroppen ansågs vara instabil och känslig för yttre påverkan från exempelvis arbete, livsstil eller klimat. ${ }^{424}$ I Tvillingsystrarna jämförs de svaga flickorna med kvinnor som har en kraftfullare och mindre förfinad konstitution, som lantflickor eller amasoner. Annas lärare säger sig föredra "en kraftig, svart skönhet ur konungens af Dahome lifamasongarde framför en liten snörd, blodfattig och hysterisk stadsfröken". ${ }^{425}$ Det samtida samhället har skapat lättsinniga, överciviliserade unga kvinnor som saknar en egentlig funktion och de avfärdas som "hvita, konfektsnaskande modedockor", vilket samtidigt understryker en rasifierad motsättning mellan starka svarta amasoner och veka vita kvinnor. ${ }^{426}$

Omnämnandet av de afrikanska amasonerna i Tvillingsystrarna avslöjar den vithetsnorm som präglar I 800-talets och det tidiga I900-talets svenska flickbok. Det är inte ovanligt att texterna uppmärksammar och emellanåt problematiserar klass-, ålders- och generationsskillnader, men människor med mörk hudfärg eller annan etnicitet ges en mer perifer roll. I en undersökning av nationell identitet i svenska flickböcker publicerade mellan I930 och I950, konstaterar Maria Nilson att svenskhet associeras med vithet och medelklass. Denna norm är outtalad och synliggörs främst i relation till personer med annan social, etnisk eller nationell bakgrund som utpekas som annorlunda eller icke-svenska. Det främmande kan framställas som exotiskt och lockande, men beskrivs vanligen som hotfullt när berättelsen utspelas inom Sveriges gränser. ${ }^{427}$ En likartad tendens återfinns i det äldre material som jag har undersökt. De grupper som oftast representerar det annorlunda är romer och resandefolk, i samtiden benämnda i föringande ordalag som "tattare". I enstaka fall inger dessa människor skräck, som i Kuylenstierna-Wensters När katten är borta då Birgit håller på att bli bestulen av en tärd, svartmuskig man. Att flickbokens protagonister kommer i kontakt med dessa grupper är dock förhållandevis ovanligt. De rör sig vanligen $i$ andra 
samhällsskikt och miljöer. Ofta figurerar det främmande i stället som exotiska eller komiska inslag i utklädningslekar och upptåg. I Flickor emellan spelar ungdomarna en "zigenarhöfding" med "en berömd taskspelartrupp" under ett födelsedagsfirande och på den välgörenhetsmarknad som de unga i Silverbjärtat. En bok för flickor (I9I8) anordnar förekommer attraktioner som till exempel"en dansande, sjungande neger i brokig halsrosett och slängande rock", det vill säga en pojke i blackface. ${ }^{428}$ Dessa grupper framstår som stereotyper snarare än levande människor ur karaktärernas perspektiv. De fungerar också indirekt som en bekräftelse av vitheten som oproblematiserad norm.

Även amasonerna i Idströms flickbok beskrivs som exotiska och annorlunda. Framställningen har emellertid mer positiva inslag genom att de kvinnliga soldaterna äger något som samtida svenskor saknar. Bondjäntan, den svarta kvinnan och pojkflickan fungerar alla som kontraster till sköra medelklassflickor. De förenas av egenskaper som hälsa, styrka och en avsaknad av förfining. Snarare än att befinna sig i ett entydigt motsatsförhållande till en vuxen vit kvinnlighet kunde dessa inordnas i ett utvecklingstänkande runt sekelskiftet I900. Att som flicka uppföra och klä sig som en pojke kunde, enligt Michelle Ann Abate, beskrivas som "an effective preparatory stage for marriage and motherhood". ${ }^{429}$ Hon visar att ett pojkaktigt beteende under flicktiden kunde betraktas som positivt för den vuxna kvinnans hälsa, under förutsättning att det upphörde i tonåren. Genom att flickan tilläts större frihet i barndomen skulle nationen få fysiskt starkare hustrur och mödrar. ${ }^{430}$ Liknande idéer framfördes i debatter om pojkars fostran runt sekelskiftet, för att motverka att pojkar skulle bli överciviliserade eller feminina. Om de tilläts att vara fria och ohämmade när de var unga, skulle de utvecklas till hårdföra män med moralisk stadga och självkontroll. ${ }^{431}$ Pojkars vildhet kunde alltså framhållas som ett ideal för båda könen, vilket kan anas av Idströms pojkflicka. Det finns dock en gräns för det primitiva eller maskulina inflytandet. Amasonerna sägs vara"vilda och ohyfsade enligt våra begrepp. Men de äro plikttrogna, modiga och handla strängt efter sina begrepp om heder och ära [...]." ${ }^{32}$ Fastän de kvinnliga soldaterna på många sätt är beundransvärda kan de bara utgöra en inspiration och inte en förebild för svenska flickor. 
Det missriktade i svensk flickuppfostran framhävs även genom en jämförelse mellan ungdomar i Sverige och Amerika. Tvillingsystrarna sammankopplar den nya världen med framstegsanda, demokrati och emancipation, vilket var vanligt i samtiden. ${ }^{433}$ Sundbecks Elsa i Upsala och Svedenborgs Hannas dagbok gör samma association, men med olika värderingar. I Sundbecks roman utgör Amerika ett avskräckande exempel, medan Svedenborgs och Idströms texter framställer landet som ett föredöme. Länderna i den gamla världen beskrivs däremot som stagnerade och traditionsbundna, i synnerhet i relation till kön:

De svenska flickorna [...] uppfostras ju så helt annorlunda, insupa från barndomen andra idéer och hållas så tillbaka af den allmänna meningen. Det mest tilldragande hos våra amerikanska flickor är deras fullkomliga frihet från all tillgjordhet - de ha en väl utvecklad kropp, en hjärtevinnande öppen blick, naturliga rörelser och ett okonstladt sätt. ${ }^{434}$

Svenska flickor framstår som konstlade och otillräckliga i jämförelse med amerikanskorna, men Idströms roman ifrågasätter samtidigt hur de amerikanska kvinnorna skulle bemötas i Sverige, då kulturerna framställs som väsensskilda. Amerikanskornas enkla, rättframma uppförande sägs kunna uppfattas som vulgärt eller okvinnligt av människor som inte är vana vid att flickor agerar som "fria och själfständiga väsen". 435 I Sverige har således det naturliga blivit onaturligt.

Liksom många litterära pojkflickor före henne lägger Anna till slut av sig pojkplaggen och ikläder sig kvinnodräkt. I vilken mån detta innebär att protagonisten underkastar sig traditionella könsnormer eller inte är en av de mest omdiskuterade och problematiska aspekterna av berättelser om flickor i pojkkläder. ${ }^{436}$ I Annas fall innebär dock inte flickkläderna att hon bejakar en samtida flickighet, vilket framgår av klädvalen. Plaggen väljs med hänsyn till hennes bekvämlighet och hälsa: "Reformunderkläder af de bästa in- och utländska mönster - ytterdräkten bestånde af ej för lång kjol af tunt kläde och en s.k. båtmansblus af flanell i någon behaglig färg." 337 När det första exemplaret av en reformdräkt lanserades i Sverige I 885 var målet att skapa en kvinnoklädsel som var ledigare och sundare än det förhärskande modet med korsett, 
många lager underkläder och långa kjolar. Det var en fråga som drevs av kvinnosakskvinnor och dräkten anammades av vissa kvinnor inom rösträttsrörelsen, bland andra Ellen Key. Reformdräkten var en klädsel med stark politisk laddning och kallades också emancipationsklänningen. ${ }^{438}$ Valet av flickkläder i Tvillingsystrarna är i likhet med pojkkläderna ett ställningstagande mot en konventionell kvinnlighet. Anna fortsätter dessutom att ha kortklippt hår och de praktiska kvinnokläderna möjliggör ett aktivt, rörligt liv. Den extravagans och tillgjordhet som associeras med kvinnor och deras kläder avfärdas. Därmed klargörs att det i denna flickbok inte finns ett självklart samband mellan att bära klänning och att bejaka en traditionell kvinnosyn. Släktingarnas kritik att Anna inte är tillräckligt blygsam och feminin upphör inte heller när hon byter klädedräkt. Till och med i kvinnokläder representerar Anna en ny, mer maskulin kvinnlighet.

Medelklassens föreställningar om kvinnlighet kritiseras i Tvillingsystrarna genom att svenska flickor jämförs med personer som tillhör andra klasser, etniciteter och nationaliteter, men dessa fungerar främst som kontraster. Inte ens de beundrade amerikanska flickorna kan mäta sig med Anna: "Hon såg friskare och förnämare ut än de unga amerikanskorna." ${ }^{439}$ I Idströms roman definieras inte den nya kvinnan av specifika fysiska eller mentala egenskaper utan hon bedöms utifrån i vilken mån hon ger ett väsentligt bidrag till samhället. Enligt Hallberg skapas det $\mathrm{i}$ texten en motsättning mellan kvinnan som passivt objekt och aktivt subjekt. ${ }^{440}$ Syftet med den nya uppfostran är att lära kvinnor att vara självständiga och nyttiga personer snarare än prydnadssaker. Även om både Anna och systern har förlovat sig vid berättelsens slut är inte målet med den förändrade uppfostran att de ska bli starkare mödrar och bättre hustrur, som i böckerna Abate diskuterar. Den nya kvinnan beledsagas i Tvillingsystrarna av en ny man, som önskar att hustrun ska vara hans kamrat och jämlike. ${ }^{441}$ Yrken och arbetsuppgifter framställs inte heller som särskilt passande för något av könen. Hushållssysslor och politik sägs vara lika viktiga för nationens väl. Så länge människor är duktiga på det de gör spelar det ingen roll vad de arbetar med:"Man och kvinna borde mer sträfva efter att åt sig uppsöka de platser i lifvet, där de blifva dugande, än sådana, hvilka nu anses mer framskjutna och 
ansedda. Och de skola göra det, när man upphört att säga:'detta passar en man - detta en kvinna' [... ."."422 Idströms text betonar vikten av att utgå från individens fallenhet för olika sysslor snarare än föreställningar om vad som är passande arbeten för män och kvinnor. Målet med den nya uppfostran är att frambringa kvinnor som har styrkan och förmågan att bidra till samhället i den roll de själva väljer.

\section{Vuxna kvinnor}

Genom att rikta fokus mot förhållandet mellan individ och samhälle introduceras en medborgarskapsdiskurs i Idströms roman. Enligt Mitchell skedde i slutet av I 800-talet en omdefiniering av flickskap och pojkskap, där"certain gendered ideals could be enlisted to train girls for 'manhood' and (ultimately) citizenship" ${ }^{443}$ Tvillingsystrarna iscensätter en dylik process på ett bokstavligt plan, genom att den nya kvinnans förberedelse för ett utvidgat medborgerligt ansvar går via en uppfostran till pojke. Som konstaterats tidigare utgick medborgarskapet under I 800-talet från en manlig norm. Kvinnors kamp för utökade rättigheter betraktades emellanåt som ett intrång på ett manligt revir eller som en önskan att vara som män. ${ }^{444}$ Spänningsfältet mellan kön och politiskt medborgarskap kunde hanteras på olika sätt. Medan bland andra Key försökte omdefiniera medborgaren genom att skapa ett specifikt kvinnligt medborgarideal, inriktar sig Idström på att omformulera kvinnligheten och manligheten på ett sådant vis att medborgarskap ska kunna bli tillgängligt för båda könen på lika villkor. Tvillingsystrarna undersöker hur kvinnor ska kunna utvecklas till mogna och ansvarstagande medborgare, samt på vilka sätt de kan bidra till samhället. Detta sker genom framställningen av tvillingflickornas väg till vuxna kvinnor.

Berättelser om pojkflickor skildrar ofta en protest mot både kvinnlighet och vuxenhet. ${ }^{445}$ I Ebba Nordenadlers I Edsbro pension. Berättelse för flickor (I900) konstaterar pojkflickan Bet:"När jag inte blef pojke, så ville jag helst vara en liten flicka så länge som möjligt." ${ }^{446}$ Så länge flickan är ung tolereras hennes vilda beteende, men när hon kommer i puberteten ökar förväntningarna om att hon ska anpassa sig till samtidens könsnormer. Likartade handlingsstrukturer återfinns i många kvinnliga 
utvecklingsromaner, men är särskilt framträdande i berättelser om pojkflickor. Att växa upp till kvinna under I800-talet har ibland beskrivits som att"växa ner", det vill säga att flickan hämmas och får mer begränsat handlingsutrymme. ${ }^{447}$ Lorna Ellis menar dock i Appearing to Diminish. Female Development and the British Bildungsroman, 1750-1850 (I999) att en likartad anpassning gestaltas i både manliga och kvinnliga bildningsromaner, och kan snarare sägas utgöra en central aspekt av litterära skildringar av att uppnå mognad:

By teaching protagonists how to understand and work within the limits of their societies, authors of female Bildungsromane allow their heroines to mature or "grow up" - to understand themselves and their relationship to their environment, and to negotiate that environment in order to maintain some form of agency. However, the process of learning to understand and work within the limits of society simultaneously forces the heroine to decrease her sphere of action or to "grow down."448

I en tid då kvinnors myndighet och rätt att bestämma över sig själva och sin egendom debatterades, blev frågor om mognad av stor betydelse för kvinnorörelsen. ${ }^{449}$ Genom att flickors uppfostran och utbildning reformerades eftersträvade man att kvinnor skulle bli mer mogna och demonstrera att de var förmögna att ta ansvar såväl för sin ekonomi som sin framtid. Därigenom kunde kvinnorna bevisa att de var redo att få samma rättigheter som männen och ett fullvärdigt medborgarskap. ${ }^{450}$ Snarare än att skapa en motsättning mellan pojkflickans fria liv och en begränsad tillvaro som vuxen kvinna, ställer Idströms flickbok olika föreställningar om mognad mot varandra och diskuterar hur de påverkar kvinnornas möjligheter att styra över sina liv.

I Tvillingsystrarna inträder Gunlög till synes i vuxenvärlden före Anna. Året hon fyller femton slutar hon skolan och konfirmerar sig. Dessa händelser visade att flickan inträtt i vuxenlivet i I 800-talets samhälle, vilket även markerades genom att hon bar längre kjolar och håret uppsatt. Efter konfirmationen antar Gunlög den yttre vuxenhetens tecken och går på baler för vuxna. Dagarna tillbringar hon med olika nöjen och att drömma om sin blivande make. Anna fortsätter däremot 
att leva på samma sätt som hon gjort sedan hon var barn och hennes kropp är en flickas. Hon beskrivs som "blott en lång, gänglig skolflicka, då systern redan var en ung dam". hennes vänner vill vara "stora damer", är Anna nöjd med att uppföra sig som och bli betraktad som ett barn. ${ }^{452}$ Gunlögs sociala status som vuxen motsvaras emellertid inte av känslomässig mognad eller ansvarstagande. Hon är lättsinnig, självisk, slösaktig och oförmögen att ta hand om sig själv och andra. Systern har tvärtom i unga år fått lära sig att vara ekonomisk och bidrar till en grannfamiljs försörjning. Anna är empatisk, omtänksam och uppför sig mestadels på ett ansvarstagande sätt, i varje fall efter att hon blivit för gammal för pojkstreck.

Tvillingsystrarna kontrasterar en yttre och en inre mognad. Skillnaderna mellan de två unga kvinnorna kvarstår efter att även Anna har konfirmerat sig:

Vintern efter konfirmationen - och medan Gunlög gladde sig åt tillbedjare i mängd och undrade, hvem som skulle bli"den rätte", studerade Anna för brinnande lifvet, och på våren, samtidigt med att Gunlög fick sina första tandplomber, eröfrade hon den vita mössan. ${ }^{453}$

Vid sjutton års ålder har Anna tagit studenten genom hårt och målmedvetet arbete. Systerns främsta prestation är att ha förstört sina tänder genom tveksamma kostval. Även om Gunlög är släktens ögonsten ifrågasätts denna värdering av hennes uppförande i texten. Att bära vuxenhetens yttre tecken eller att ha en välutvecklad kropp framstår som mindre viktiga kriterier på mognad. Ett moraliskt sinnelag, självständighet, flit och osjälviskhet framställs som mer centrala och det var också egenskaper som kännetecknade en god medborgare i I 800-talets samhälle. ${ }^{454}$ En traditionell kvinnouppfostran och livsstil kritiseras i Idströms berättelse, eftersom den inte förbereder kvinnan för att vare sig ta ansvar för sig själv eller samhällets utveckling.

Faster Ebbas uppfostringsexperiment startar som hämnd, men förvandlas till ett ideologiskt drivet projekt. Anna förkroppsligar fasterns föreställning om en bättre framtid för kvinnan. Den äldre kvinnan önskar att hon ska bli en samhällsreformator och fullborda Fredrika Bre- 
mers oavslutade arbete. Den främsta måltavlan för romanens kritik är de lagar och normer som hindrar flickor från att nå sin fulla potential och hitta en meningsfull sysselsättning. Genom faster Ebbas frustration och besvikelser gestaltas abstrakta idéer om kvinnans underordning på ett konkret vis. Hon hävdar att hon skulle ha kunnat vara en lyckligare och mer samhällsnyttig medborgare om hon fått en annan uppväxt:

Jag kunde ha dundrat mot orättvisor och sådant uppe i riksdagen - jag kunde ha blifvit publicist eller vetenskapskvinna eller stått i spetsen för något affärsföretag. I stället sattes som måttstock för min förmåga en märkduk och några franska glosor och litet hushållssysslor. Men detta var inte nog för mitt lifliga lynne - tiden blef mig lång och måste fyllas ut med något, och detta blef kvinnors vanliga, och jag blef som så många andra ett offer för fåfänga och njutningslystnad - dubbelt olyckligt för mig. ${ }^{455}$

Tvillingsystrarna kritiserar därmed indirekt de lagar som bara några decennier tidigare hindrat alla kvinnor från att utöva de nämnda yrkena och fortfarande inte tillät dem att delta i riksdagsarbetet. Kvinnors färdigheter och förmågor erkänns inte, vilket framställs som en förlust för både individen och samhället. Om kvinnorna var fåfänga och odugliga berodde det på att de inte uppmuntrades att tillbringa sin tid på ett förnuftigt vis.

Idströms flickbok innehåller få explicita referenser till medborgarfrågor som juridiska reformer eller rösträtt. Trots det är det tydligt att diskussionen om kvinnans rättigheter utgår från en egalitär princip. Tvillingsystrarna visualiserar olika vuxenliv för syskonen och indirekt också för den samtida kvinnan. Gunlög avser att bli en hemmafru som uppfostrar barnen och assisterar maken i hans forskning. Hon kommer även att utöva moraliskt inflytande över de råbarkade sjömännen på mannens skepp. Hennes framtid befinner sig inom kvinnans traditionella sfär och hon beskrivs som "das ewig weibliche" i deras hem på havet. ${ }^{456}$ Anna kommer också att arbeta sida vid sida med maken, men i högre grad utanför hemmet. Tillsammans kommer de att driva hans stora fabriker och ta sig an arbetarnas utbildning genom att bygga skolor och ge populärvetenskapliga föreläsningar. Även om systrarnas 
verksamhetsområden och färdigheter skiljer sig åt kommer båda att ha en undervisande roll för barn och vuxna.

Tvillingarnas sysselsättningar har många likheter med de yrken som Key framhöll som passande för kvinnan i Missbrukad kvinnokraft. Idström begränsar dock inte kvinnor till att vara lärare, sjukvårdare eller någon annan befattning, vilket är en väsentlig skillnad. Keys främsta invändning mot kvinnorörelsen var att den inte hade diskuterat vilka samhällssysslor som var passande för kvinnan:"Kvinnoemancipationens stora misstag har varit detta: att hafva lagt hufvudvikten på kvinnans arbete, icke på hennes arbetsområde." 457 Hennes föreställning om en kvinnlig medborgare formulerades som en "samhällsmoder" och hon argumenterade för utökade kvinnliga rättigheter med utgångspunkt $i$ kvinnors skillnad från männen. Genom att föra in ett moderligt, vårdande inslag i en tidigare manligt dominerad politik skulle kvinnornas närvaro återställa en samhällelig balans. ${ }^{458}$ Idström utgick däremot från en liberal, individualistisk utgångspunkt, eller som hon formulerar det i Misslyckad kvinnokraft: "Väsenolikheter komma väl alltid att förefinnas, men sannolikt mer emellan människor än emellan könen." ${ }^{459}$ Hennes medborgarideal grundades på gemensamma mänskliga egenskaper snarare än en kvinnlig särart. Såväl kvinnor som män borde tillåtas att bidra till samhället med utgångspunkt i sina färdigheter, inte sitt kön. Det kunde innebära att skapa ett gott hem för familjen, som Gunlög, att bli en social reformator, som Anna, eller något helt annat.

Romanen avslutas med en mer positiv bild av kvinnlighet och tvillingsystrarnas återförening. I stället för att fortsätta framstå som varandras motsatser utvecklas båda flickorna till mogna, nya kvinnor men på olika sätt. Under Annas inflytande upphör Gunlög att vara fåfäng och självisk, och visar sig då äga en god omdömesförmåga. Hon beskrivs som mer känslomässigt mogen än systern och detta drag är ett resultat av hennes uppfostran till flicka. Även om Annas uppväxt har utvecklat hennes intellekt och självständighet, har hon svårt för att läsa andra människors känslor och behöver systerns hjälp. Därigenom visas att också delar av en traditionell kvinnlighet och kvinnlig fostran har ett värde. Hallberg menar att det ideala uppfostringsprogrammet i Tvillingsystrarna förenar manligt och kvinnligt. ${ }^{460}$ Detta sker genom att 
skillnaden mellan flickors och pojkars uppväxt undermineras. I texten betonas att barnuppfostran bör vara könsneutral: "Gossar och flickor skola uppfostras lika. Framför allt måste de bli modiga, starka och friska; äro de blott detta, så äro de också goda" ${ }^{" 461}$ Hälsa och styrka blir den nya utgångspunkten i stället för föreställningar om kvinnligt och manligt. När Gunlög börjar klä sig i reformdräkt och klipper håret som systern framträder likheterna mellan tvillingarna igen: "Alla förvåna sig öfver likheten emellan dem [...]. Men Gunlög är något mindre och spädare. Alla äro öfverens om att hon är en mycket söt liten kvinna, men att den ståtliga och graciösa Anna är snarlik en ung gudinna," ${ }^{462}$ Gunlög är fortsatt den nättare och kvinnligare av dem, men föreställningen om vad som utgör ett äkta kvinnligt utseende har vidgats och omdefinierats. Vid bokens slut har Annas kvinnliga maskulinitet accepterats och hyllas.

Tvillingsystrarna skrevs under en omvälvande tid i det svenska samhället. Den iscensätter en utopisk utveckling i den realistiska romanens form. Berättelsen skildrar både de hinder som mötte kvinnor när de intog nya platser i samhället och inspirerande nya möjligheter. Många flickböcker om pojkflickor har kritiserats för att den rebelliska hjältinnan slutligen anpassar sig till ett mer konventionellt kvinnligt beteende. De beskriver ett slags "tomboy taming" ${ }^{463}$ Bejakandet av kvinnligheten sammanfaller oftast med att flickan blir vuxen, vilket förpassar pojkflicksperioden till en övergångsfas på väg mot mognad. Idströms roman följer inte ett sådant mönster. Anna slutar bära pojkkläder, men hennes självständiga och självsäkra uppförande förändras inte. Att klä sig i kvinnokläder likställs inte heller med att bli vuxen i texten. Det är inte pojkflickan som blir reformerad utan i stället sker en omformulering av normerna för såväl kvinnlighet som vuxenhet. I Tvillingsystrarna syns ingen oro för att en kvinnlig särart ska gå förlorad när världen förändras. Tvärtom frigör uppfostran till pojke en dold potential i Anna och låter henne växa upp till en ny kvinna med oändliga möjligheter, i en värld där" alla utsikter stå öppna". ${ }^{464}$ 